Article

\title{
Investigation of Nonthermal Plasma Assisted Charcoal Gasification for Production of Hydrogen-Rich Syngas
}

\author{
Yin Pang ${ }^{1, *}$, Thomas Hammer ${ }^{2}$, Dominik Müller ${ }^{1}$ and Jürgen Karl ${ }^{1}$ \\ 1 Chair of Energy Process Engineering, Friedrich-Alexander-Universität Erlangen-Nürnberg, Fürther Str. 244f, \\ 90429 Nürnberg, Germany; dominik.mueller@fau.de (D.M.); juergen.karl@fau.de (J.K.) \\ 2 Siemens AG, Corporate Technology, Research on Energy and Electronics, Günther-Scharowsky-Str. 1, \\ 91058 Erlangen, Germany; thomas.hammer@siemens.com \\ * Correspondence: yin.pang@fau.de; Tel.: +49-911-5302-9032
}

Received: 30 January 2019; Accepted: 19 February 2019; Published: 21 February 2019

check for updates

\begin{abstract}
The motivation of this work is to investigate experimentally the influence of nonthermal plasma (NTP) application on the reaction kinetics of atmospheric pressure steam gasification of charcoal using a thermostatically controlled drop tube reactor. A gliding-arc generator provides about $1 \mathrm{~kW}$ electrical power NTP. For comparison thermal gasification is investigated under comparable flow and specific energy input conditions providing additional heat to the steam. Optical temperature measurement $20 \mathrm{~cm}$ flow down of the NTP zone is utilized to characterize the specific enthalpy of the reactive flow. The composition of produced syngas is measured by a gas analyzer and used for the calculation of gas flow rates. The results show a NTP-enhancement on the production of individual syngas components $\left(\mathrm{H}_{2}, \mathrm{CO}, \mathrm{CH}_{4}\right)$, especially on hydrogen production by around $39 \%$. The syngas-based carbon conversion and hydrogen release are calculated from the carbon and hydrogen balance between the correspondent content in syngas and in the feedstock. The NTP promoted the carbon conversion and hydrogen release by $25 \%$ and $31 \%$, respectively. The first-order reaction kinetics are determined by data-fitting in an Arrhenius diagram. The plasma enhanced the reaction rate coefficients by $27 \%$. Based on experimental results and other literature, possible plasma-induced reactions are proposed.
\end{abstract}

Keywords: nonthermal plasma; charcoal gasification; carbon conversion; hydrogen release; reaction kinetics; reaction mechanism

\section{Introduction}

Charcoal or coke is one of the major products from pyrolysis reactions besides gases and tar [1]. Compared to biomass pyrolysis, the gasification of charcoal or coke is much slower due to slow reaction kinetics limited by mass transfer, e.g., pore diffusion and external mass transfer [2]. Increasing the reaction rate of charcoal gasification could have the benefit of a smaller reactor size, lower capital costs and higher output.

Several influence parameters can enhance the charcoal/coke gasification kinetics. Among them, pyrolysis conditions, origin of feedstock, working medium and mineral content are discussed here.

The test condition of pyrolysis determines the structure of charcoal and thus the reaction rate. This could be explained by the influence of macro-, mecro- and micropores generated during pyrolysis. $\mathrm{Li}$ et al. [3] prepared char samples at different pyrolysis temperature ranging from $800{ }^{\circ} \mathrm{C}$ to $1200{ }^{\circ} \mathrm{C}$ for the $\mathrm{CO}_{2}$ gasification reaction. The results showed a decrease in gasification reactivity by increasing pyrolysis temperature. With rising temperature, the pore structure melted, collapsed and jointed together, which led to decrease of specific areas/active sites. Bui et al. [4] studied the influence of 
pyrolysis pressure between 1 and 20 bar on charcoal gasification kinetics with $\mathrm{CO}_{2}$ and concluded lower reaction rates at higher pyrolysis pressure.

The origin of feedstock influences the internal chemical and physical structure. Yuan et al. [5] gasified three different char samples from rice straw, chinar leaves and pine sawdust. During gasification, the char structure of pine straw was destructed due to melting and accumulation, which led to smaller specific surface area and lower gasification rate. The sample from chinar leaves, with high porosity and specific surface area, had the highest gasification rate. Wang et al. [6] investigated six char samples in a thermobalance at atmospheric pressure with $\mathrm{CO}_{2}$. The results showed herbaceous residues (pine sawdust, bamboo sawdust) had a faster gasification reactivity than wooden residues (peanut shell, maize cob, wheat straw, rice lemma). Dahou et al. [7] studied gasification kinetics with water steam using six different feedstock in a thermo-gravimetric balance. Among them, residues from apple orchard, apricot orchard and vineyard showed highest conversion rates, while residues from rice husk and wheat straw reacted with the slowest kinetics.

Different working medium influences reaction kinetics during charcoal gasification. The gasification agent can be chosen between carbon dioxide, water steam, (oxygen-enriched) air and pure oxygen, with increasing reaction kinetics. Yoon and Lee [8] concluded from the experimental results that the carbon conversion of pure steam gasification is lower than the conversion using steam-air mixture. Guizani et al. [9] concluded experimentally that the reactivity of char using $\mathrm{H}_{2} \mathrm{O}$ as agent was almost two times faster than using $\mathrm{CO}_{2}$. Reschmeier and Karl [10] determined that the reaction kinetics using water steam were faster than using carbon dioxide.

Many researchers have studied the catalytic influence of mineral content in the ash on charcoal gasification reactions. Bouraoui et al. [11] varied the ratio of $\mathrm{K} / \mathrm{Si}$-ratio between 0.2 and 3.8 during $\mathrm{CO}_{2}$ gasification at $800{ }^{\circ} \mathrm{C}$ and concluded an acceleration of reaction by a $\mathrm{K} / \mathrm{Si}$-ratio higher than 3 at high conversion degree. Hengel and Walker [12] found a strong catalytic influence caused by calcium-dosage during char gasification.

Recently, research activities have been reported in the field of plasma-assisted charcoal/coke gasification.

Tamosiunas et al. [13] used a thermal plasma torch to gasify olive-derived charcoal with water steam. The DC arc plasma torch provided approximately $50 \mathrm{~kW}$ to the gasification reactor. The syngas consisted mainly of $\mathrm{CO}, \mathrm{H}_{2}$ and $\mathrm{CO}_{2}$ with concentrations of $41 \%, 13 \%$ and $13 \%$, respectively. Yoon and Lee [8] gasified charcoal powder using microwave plasma operated by steam-air-mixture. For plasma gasification operated by pure water steam, a maximum hydrogen content of ca. $60 \%$ and a cold gas efficiency of ca. $23 \%$ have been reported.

The major research focus of this work is to investigate the influence of nonthermal plasma (NTP) on charcoal gasification compared to conventional thermal gasification at similar test conditions, in particular with respect to specific energy input.

\section{Experiments}

\subsection{Concept}

The major motivation of this work is to investigate the influence of nonthermal plasma (NTP) on charcoal gasification based on a comparison between plasma and thermal cases at similar test conditions. The NTP, also known as non-equilibrium plasma, does not have a thermodynamic equilibrium. Mean electron energy, degree of ionization and concentrations of excited species and radicals correspond to temperatures substantially higher than the kinetic gas temperature. This can only be achieved by taking measures impeding the establishment of thermal equilibrium, such as pulsed power supply or strong spatial gradients. The definitions of different temperature parameters and their typical ranges can be found in [14].

In the case of NTP-assisted gasification, electric power generating the electrical gas discharge plasma substitutes a fraction of the thermal power fed to a conventional gasification process. The NTP 
generated in the water steam interacts with the charcoal particles by means of ionic reactions, radical reactions and heating. The contact time of the particles with the NTP depends on the type of gasification reactor and the type of NTP. In our experiments, a drop tube reactor having a height of $4 \mathrm{~m}$ and an alternating current gliding arc generator operated at a frequency of about $90 \mathrm{kHz}$ are utilized. Due to the strongly filamentary character of the gliding arc plasma fluctuating in space and time the contacting time of the particles with the NTP is expected to be very short as compared to the residence time in the drop tube reactor. Since ionization and radical formation in the NTP filaments takes place on the sub-microsecond time scale, thermally induced reactions are slow as compared to NTP induced ion and radical reactions as long as the gas temperature is not too high (i.e., below $3500 \mathrm{~K}$ ).

To give evidence about NTP effects, it is essential to perform thermal and NTP-assisted gasification under comparable conditions (including feed flows and net specific energy input) and compare the syngas compositions and yields. The specific energy input is characterized by means of optical temperature measurement $15-20 \mathrm{~cm}$ downstream of the plasma zone [15]. Since thermalization due to radical reactions and ion recombination takes place on the time scale of micro- to milli-seconds this temperature is assumed to be representative for the specific energy input not only for the thermal gasification case but also for the NTP assisted gasification case.

\subsection{Test-Rig}

The test-rig is explicitly described in a previous publication [16]. Figure 1 presents a general overview of the used test facility. A double-lead screw conveyor (Company Coperion K-TRON, K-CV-KT20, Gelnhausen-Hailer, Germany) feeds charcoal powder with nitrogen purge into the reactor. The nitrogen is also used as a tracer for gas analysis. A steam generator provides the gasification reaction with two steam flows: the primary water steam is fed into the plasma generator as working medium and the secondary steam flow is used to vary the S/C-ratio. In the reference thermal gasification, a steam superheater heats the primary water steam to achieve similar gas temperatures.

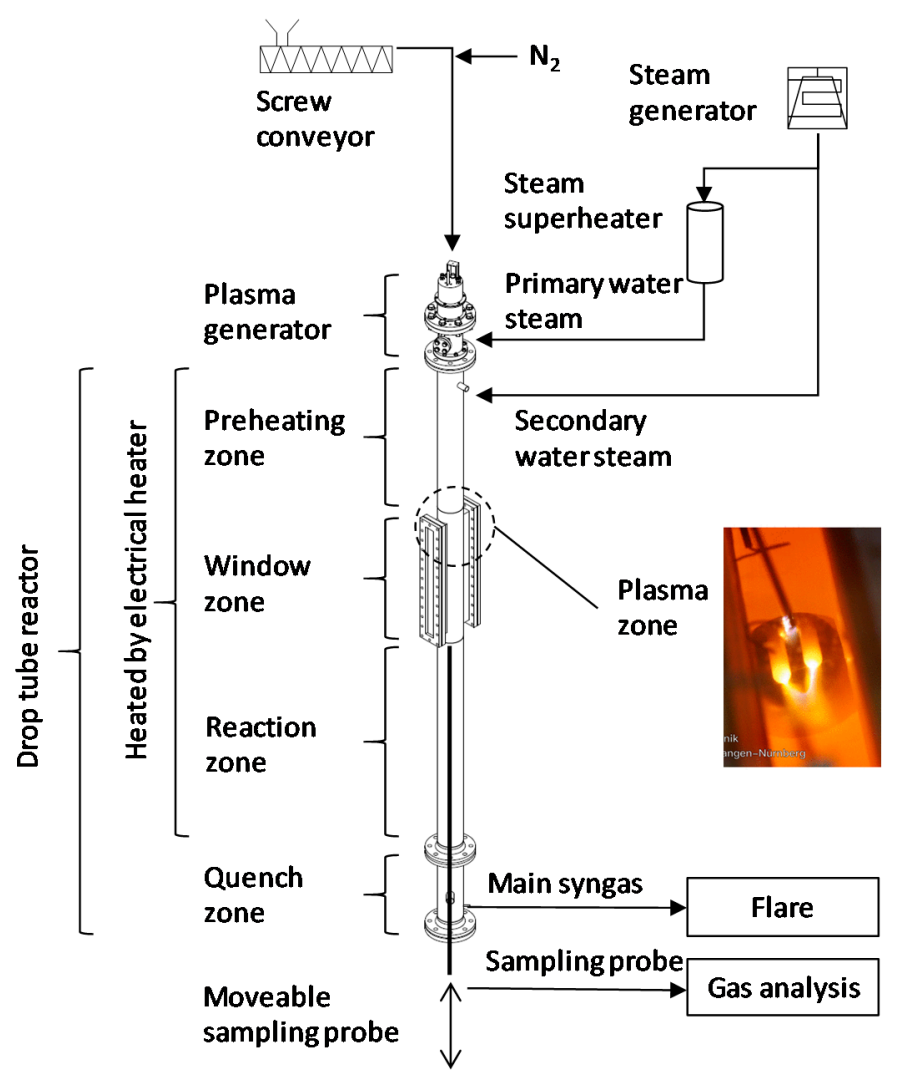

Figure 1. Test facility for plasma-assisted charcoal steam gasification (modified from [16]). 
The nonthermal plasma generator has two gliding-arc electrodes with a length of ca. $1.1 \mathrm{~m}$. The plasma arc is triggered by max. $10 \mathrm{kV}$ between a gap distance of electrodes of around $2 \mathrm{~mm}$. In the upper part of the window zone, in which two rectangular quartz glasses are installed, the generated fluctuating plasma arc can be observed and measured optically $[14,15]$, in which the results showed no substantial deviations (less than $200^{\circ} \mathrm{C}$ ) in gas temperature between NTP and thermal cases.

The drop tube reactor consists of preheating, window, reaction and quench zones. An electrical heater heats and maintains the preheating, window and reaction zones to a defined experimental temperature. The heating of the secondary water steam takes place in the preheating zone. In the beginning of the window zone, the plasma arc is triggered, and two water steam flows joint together. The fed charcoal particles pass through the fluctuating plasma area and react with the plasma mixture. A vertical moveable sampling probe withdraws the produced syngas at a defined position for gas analysis.

\subsection{Test Conditions}

Table 1 describes the properties of charcoal powder used in this work compared to two literature works. The determination of moisture, proximate analysis and ultimate analysis in this work were carried out according to German DIN (Deutsches Institut für Normung) standards [17-21]. Except for moisture content, the feedstock used in this work and in literature, contains a similar elementary composition.

Table 1. Proximate and ultimate analysis of charcoal samples used in this work and comparable literature.

\begin{tabular}{|c|c|c|c|}
\hline Sources: & This Work & Tamosiunas et al. [13] & Yoon and Lee [8] \\
\hline Fuel Type & $\begin{array}{c}\text { Charcoal } \\
\text { (derived from wood) }\end{array}$ & $\begin{array}{c}\text { Charcoal } \\
\text { (derived from Olive pomace) }\end{array}$ & $\begin{array}{c}\text { Charcoal } \\
\text { (derived from oak) }\end{array}$ \\
\hline Moisture (wt.\%) & 4.6 & 22 & 0.6 \\
\hline \multicolumn{4}{|l|}{$\begin{array}{l}\text { Proximate analysis } \\
\text { (wt.\%, dry) }\end{array}$} \\
\hline Volatile & 21.3 & 17.4 & 27.6 \\
\hline Ash & 2.3 & 5.6 & 1.4 \\
\hline Fixed carbon & 76.4 & 77 & 70.4 \\
\hline \multicolumn{4}{|l|}{$\begin{array}{l}\text { Ultimate analysis } \\
\text { (wt.\%, dry) }\end{array}$} \\
\hline Carbon & 84.5 & 80.4 & 83.3 \\
\hline Hydrogen & 3.1 & 2.9 & 3.6 \\
\hline Nitrogen & 0.5 & 0.4 & 0.4 \\
\hline Oxygen & 9.2 & 16.3 & 11.2 \\
\hline
\end{tabular}

Table 2 presents the test conditions in this work compared to the selected literature. In this work, the particle size of charcoal powder varies between 45 and $250 \mu \mathrm{m}$ with two categories. A mass flow of $0.16 \mathrm{~kg} / \mathrm{h}$ of charcoal powder is fed with $4 \mathrm{~L} / \mathrm{min}$ nitrogen purge into the reactor. The sum of primary $(6 \mathrm{~kg} / \mathrm{h})$ and secondary $(2 \mathrm{~kg} / \mathrm{h})$ water steam flows is $8 \mathrm{~kg} / \mathrm{h}$. The plasma generator supplies totally $0.9 \mathrm{~kW}$ power into the reaction. The measured operating current amplitude lying between 0.4 and 0.7 A shows clearly nonthermal characteristics; see [16]. The drop tube reactor has around $0.1 \mathrm{~m}$ in diameter and $4 \mathrm{~m}$ in length. The wall temperature of the reactor is measured at the outer surface by 9 thermocouples (type K) between 700 and $950{ }^{\circ} \mathrm{C}$. The gasification takes place at atmospheric pressure. In thermal cases, the inlet temperature of primary water steam is increased to $650{ }^{\circ} \mathrm{C}$. Therefore, the energy input can be calculated from the isobaric water capacity (ca. $2 \mathrm{~kJ} / \mathrm{kg} \mathrm{K}$ ), mass flow rate of primary water steam $(6 \mathrm{~kg} / \mathrm{h})$ and the temperature difference $(380 \mathrm{~K})$ to be ca. $1.3 \mathrm{~kW}$. This shows the energy input in both cases is in a similar range.

The simplified charcoal structure has been adopted from Backreedy et al. [22], see Figure 2. This is used for the discussion of NTP reaction mechanism in Chapter 3.7. 
Table 2. Test conditions of plasma-assisted charcoal gasification of this work and comparable literature.

\begin{tabular}{|c|c|c|c|}
\hline Sources: & This Work & Tamosiunas et al. [13] & Yoon and Lee [8] \\
\hline \multicolumn{4}{|l|}{ Feedstock } \\
\hline Particle size $(\mu \mathrm{m})$ & $45-125 ; 125-250$ & $<2000$ & 75 \\
\hline Mass flow $(\mathrm{kg} / \mathrm{h})$ & 0.16 & 4.7 & 1.3 \\
\hline Nitrogen purge (L/min) & 4 & - & - \\
\hline \multicolumn{4}{|l|}{ Steam } \\
\hline Flow rate $(\mathrm{kg} / \mathrm{h})$ & 8 & 12.7 & 2.2 \\
\hline Temperature $\left({ }^{\circ} \mathrm{C}\right)$ & $\begin{array}{l}270 \text { (plasma); } \\
650 \text { (thermal) }\end{array}$ & n.a. & $>100$ \\
\hline \multicolumn{4}{|l|}{ Plasma } \\
\hline Electric power $(\mathrm{kW})$ & $\begin{array}{l}0.9 \text { (plasma); } \\
0 \text { (thermal) }\end{array}$ & 50 & 5 \\
\hline $\begin{array}{l}\text { Current amplitude }(\mathrm{A}) \\
\text { Electric heater }\end{array}$ & $0.4-0.7[16]$ & 180 & n.a. \\
\hline Heating power (kW) & 2.5 & - & - \\
\hline Reactor & cylindrical & cylindrical & cylindrical \\
\hline Diameter (m) & 0.1 & 0.4 & 0.058 \\
\hline Length (m) & 4 & 1 & 0.1 \\
\hline Wall temperature $\left({ }^{\circ} \mathrm{C}\right)$ & $700-950$ & n.a. & n.a. \\
\hline Pressure & atm. & atm. & atm. \\
\hline
\end{tabular}

n.a.: not available; atm.: atmospheric.

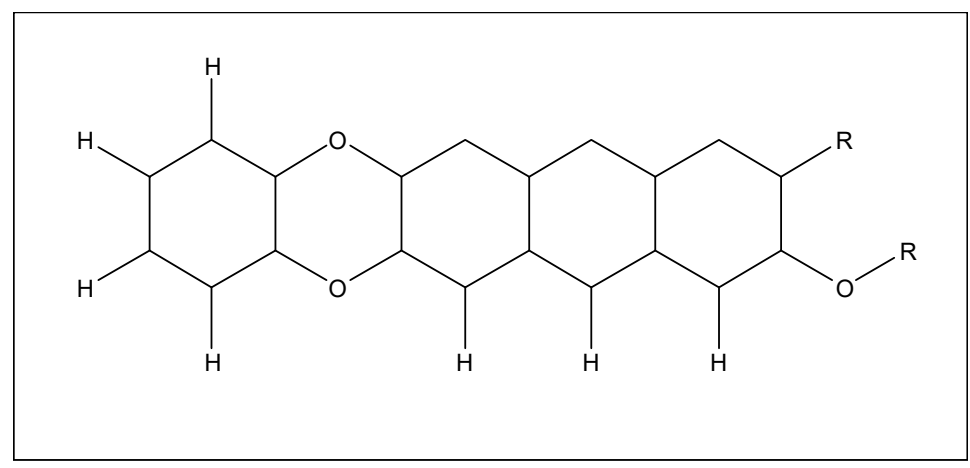

Figure 2. Simplified biomass char matrix (adopted from [22]).

In addition to plasma and thermal gasification, in this work, another test series was conducted to determine the hydrogen production due to water dissociation. The only difference compared to plasma gasification is that no fuel is added. The hydrogen production from steam plasma operation without fuel dosage is measured and calculated to be $0.061 \pm 0.005 \mathrm{~L} / \mathrm{min}$, which is about $10 \%$ of the total hydrogen production (shown in Chapter 3.2) during charcoal steam gasification.

\section{Results}

\subsection{Syngas Composition}

The syngas composition, including $\mathrm{H}_{2}, \mathrm{CO}, \mathrm{CH}_{4}$ and $\mathrm{CO}_{2}$, is measured by a gas analyzer (Company ABB, AO2020 system, Mannheim, Germany). The temperature, used as the vertical axis in this section, is the gas temperature, which is optically measured inside the drop tube reactor [14,15].

Figure 3 shows the syngas composition in case of plasma and thermal gasification with systematic errors at dry-basis. At lower temperatures, large differences in hydrogen content can be explained by the plasma-induced reactions. The C-H bonds (see Figure 2) could potentially be broken by electron impact forming hydrogen radicals. These could recombine, forming hydrogen molecules. However, reactions with $\mathrm{OH}$ - and H-radicals formed due to nonthermal plasma dissociation of water steam are possible as well (see Chapter 3.7). Further investigations would be required to check which reaction pathway is the 
dominating one. With the rising gas temperature, the hydrogen content increases rapidly in the thermal case due to enhanced steam gasification (1). Thus, the difference between two cases gets smaller.

$$
\mathrm{CH}_{n} \mathrm{O}_{\mathrm{m}}+(1-\mathrm{m}) \mathrm{H}_{2} \mathrm{O} \rightarrow \mathrm{CO}+(0.5 \mathrm{n}+1-\mathrm{m}) \mathrm{H}_{2}
$$

The concentrations of methane and carbon monoxide decreases with increasing gas temperature in the reactor. The content of carbon dioxide decreases slightly. In lower temperature range, the measurement points are determined with relatively large errors due to nitrogen dilution.

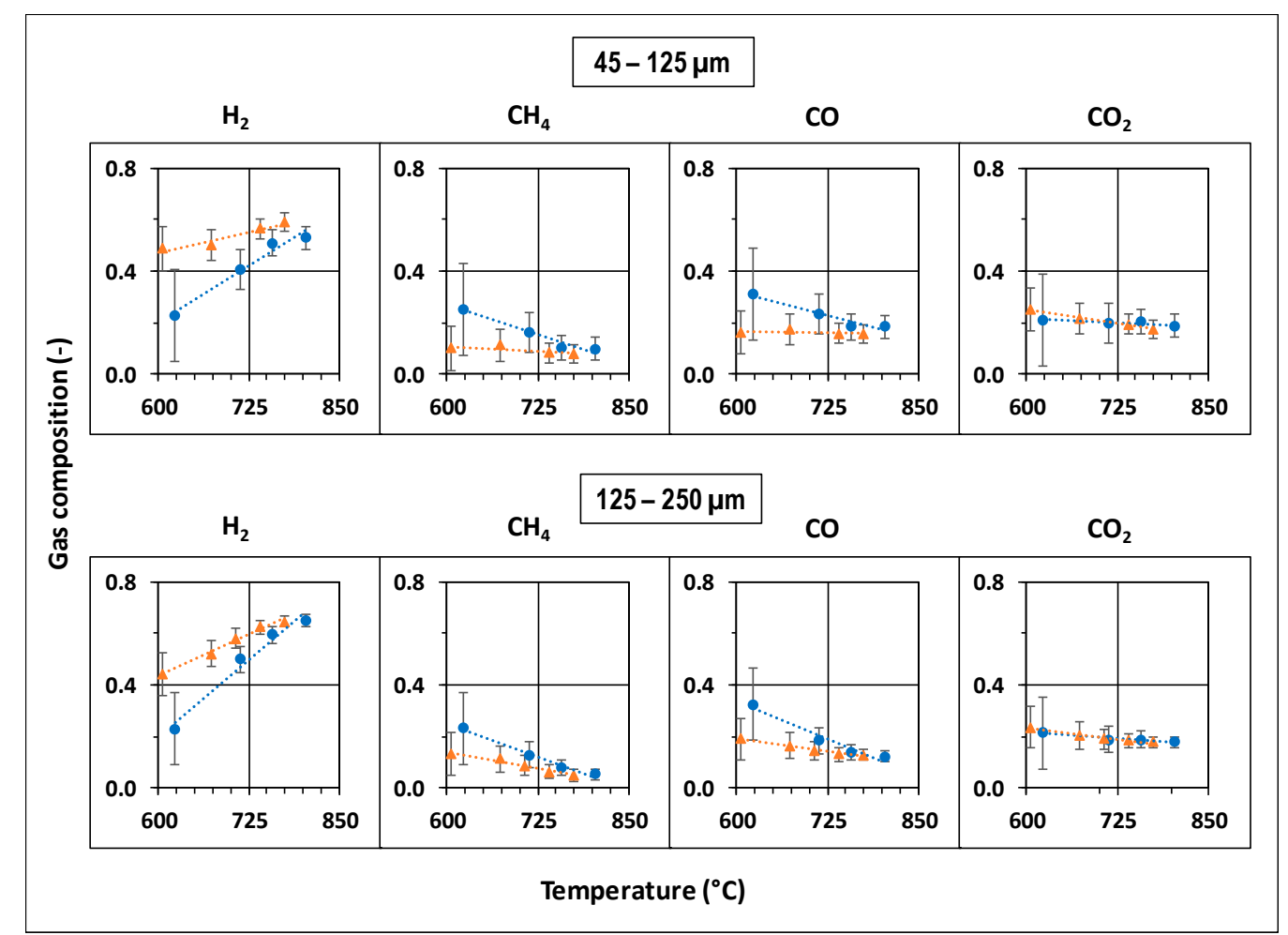

Figure 3. Syngas composition with dotted trend lines and systematic errors at dry-basis (orange: plasma; blue: thermal).

The measured syngas composition at $766^{\circ} \mathrm{C}$ is summarized in Table 3 and compared to the literature for similar test conditions. The comparison shows the results of this work are consistent to literature under consideration of systematic errors.

Table 3. Produced syngas composition in case of plasma and thermal charcoal gasification compared to literature.

\begin{tabular}{|c|c|c|c|c|}
\hline Sources: & $\mathrm{H}_{2}$ (vol.\%) & CO (vol.\%) & $\mathrm{CH}_{4}($ vol.\%) & $\mathrm{CO}_{2}(\mathrm{vol} . \%)$ \\
\hline This work, $d=45-125 \mathrm{~mm}, \mathrm{p}$ & $58.9 \pm 4$ & $15.8 \pm 4$ & $7.9 \pm 4$ & $17.5 \pm 4$ \\
\hline This work, $d=45-125 \mathrm{~mm}, \mathrm{t}$ & $51.0 \pm 5$ & $18.4 \pm 5$ & $10.4 \pm 5$ & $20.3 \pm 5$ \\
\hline This work, $d=125-250 \mathrm{~mm}, \mathrm{p}$ & $64.7 \pm 2$ & $12.8 \pm 2$ & $4.8 \pm 2$ & $17.7 \pm 2$ \\
\hline This work, $d=125-250 \mathrm{~mm}, \mathrm{t}$ & $59.6 \pm 3$ & $13.7 \pm 3$ & $7.9 \pm 3$ & $18.8 \pm 3$ \\
\hline Tamosiunas et al. [13] & 41.2 & 13 & - & 18.7 \\
\hline Yoon and Lee [8] & 60 & 17 & 3 & 21 \\
\hline
\end{tabular}

p: plasma case; $t$ : thermal case.

\subsection{Syngas Production}

The syngas production is calculated by its concentration and the known flow rate of nitrogen purge. 
Figure 4 presents the syngas production from plasma-assisted and thermal charcoal gasification with systematic errors at dry-basis. With increasing gas temperature, individual syngas production increased. Additionally, NTP had a clear influence on the production of $\mathrm{H}_{2}, \mathrm{CO}$ and $\mathrm{CO}_{2}$.

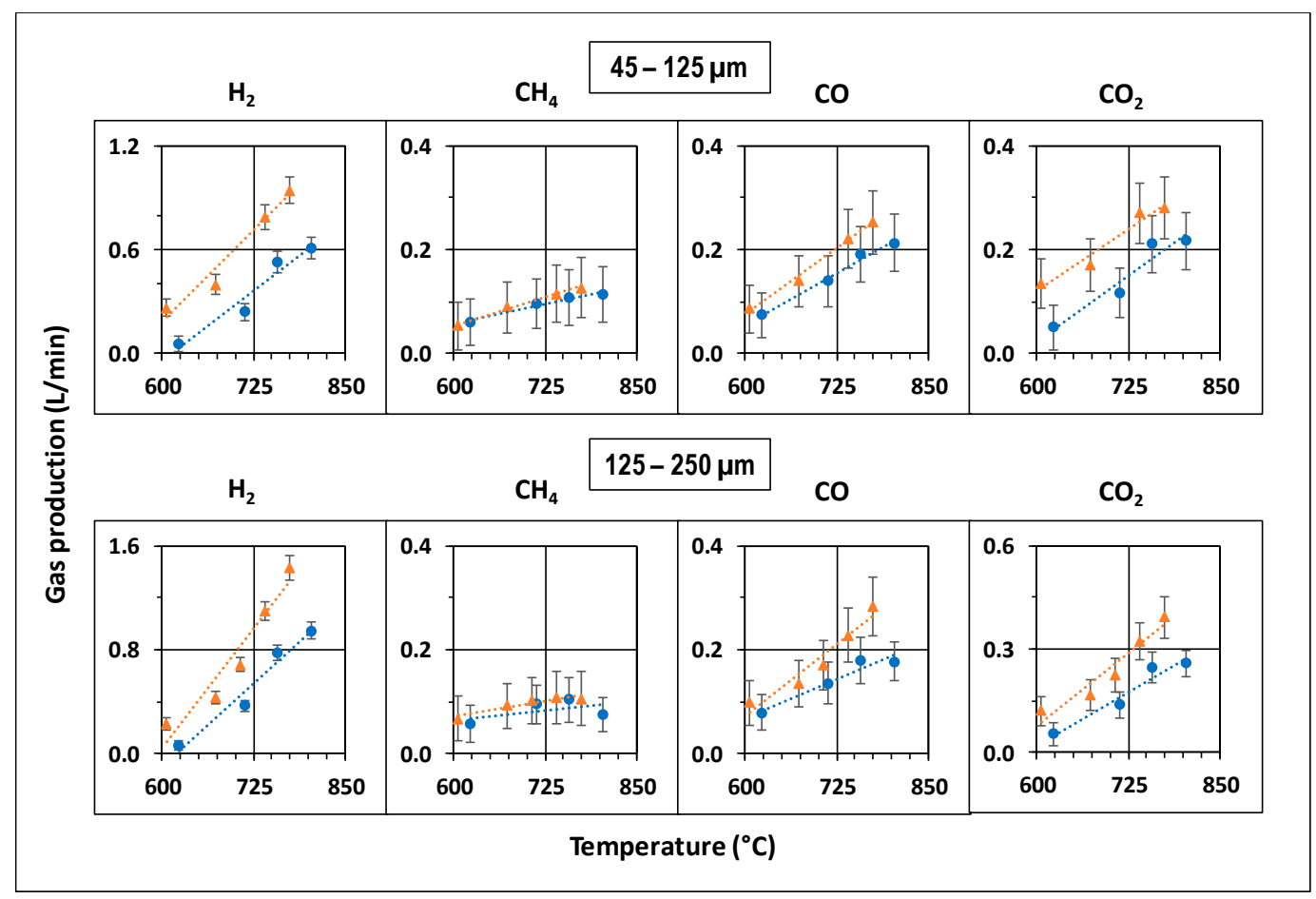

Figure 4. Syngas production with dotted trend lines and systematic errors at dry-basis (orange: plasma; blue: thermal).

The plasma enhancement in gas production at a gas temperature of $766^{\circ} \mathrm{C}$ is shown in Figure 5 . The results of particle size lying between 90 and $1400 \mu \mathrm{m}$ are adopted from a previous own publication [16]. The NTP promoted the production of hydrogen, methane, carbon monoxide and carbon dioxide by $39 \%, 8 \%, 26 \%$ and $29 \%$, respectively.

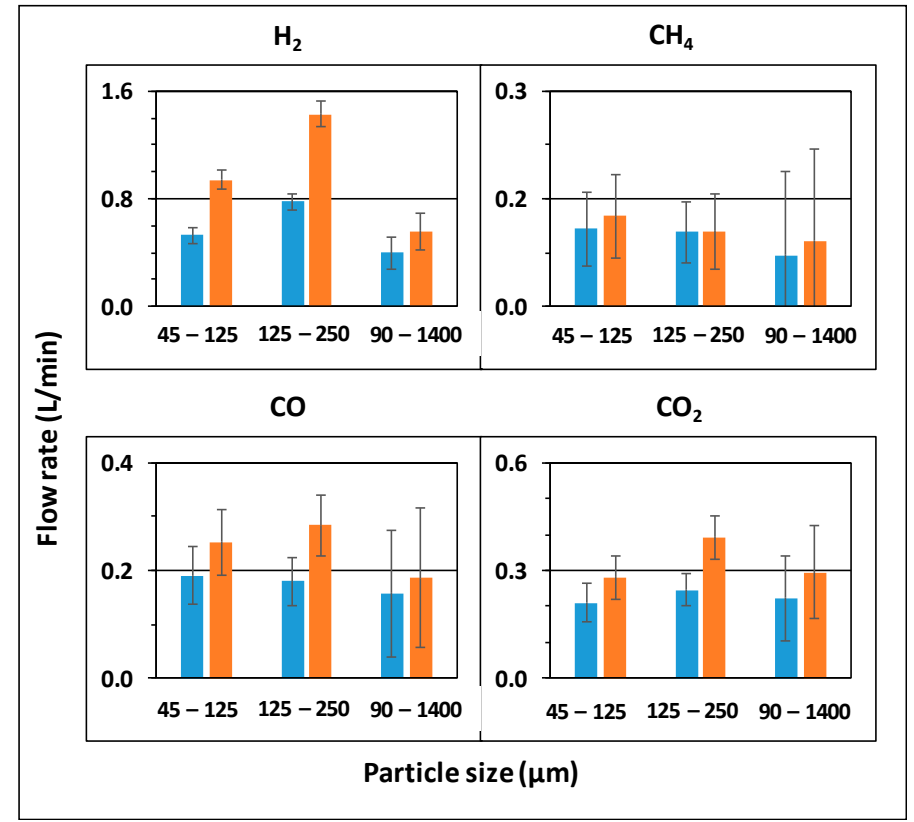

Figure 5. Plasma enhancement in syngas production at a gas temperature of $766^{\circ} \mathrm{C}$ with systematic errors. 


\subsection{Carbon Conversion}

The syngas-based carbon conversion $X_{C}$ is calculated by the carbon balance between feedstock and syngas products:

$$
X_{C}=\frac{\dot{m}_{C, C O}+\dot{m}_{C, C O 2}+\dot{m}_{C, C H 4}}{\dot{m}_{C, f u e l}}
$$

with $\dot{m}_{C, f u e l}, \dot{m}_{C, C O}, \dot{m}_{C, C O 2}$ and $\dot{m}_{C, C H 4}$ being the carbon mass flow of fuel, carbon monoxide, carbon dioxide and methane, respectively.

Figure 6 presents the calculated syngas-based carbon conversion in the case of plasma and thermal charcoal gasification with systematic errors. In (a), the calculated carbon conversion degrees of different particle sizes are presented according to the measured gas temperature in the reactor. A linear dependence can be determined and explained by the undergoing chemical reactions. In general, the plasma-assisted carbon conversion degrees are higher than that in thermal cases. In (b), charcoal particles with different sizes show very alike conversion degrees at a similar temperature of $766^{\circ} \mathrm{C}$. On average, the NTP has increased the carbon conversion by $25 \%$. Additionally, no dependence between the carbon conversion degrees and particle sizes can be found. The deviation in (b) can be explained by the fluctuation of screw conveyor, which is already considered in the shown systematic errors.

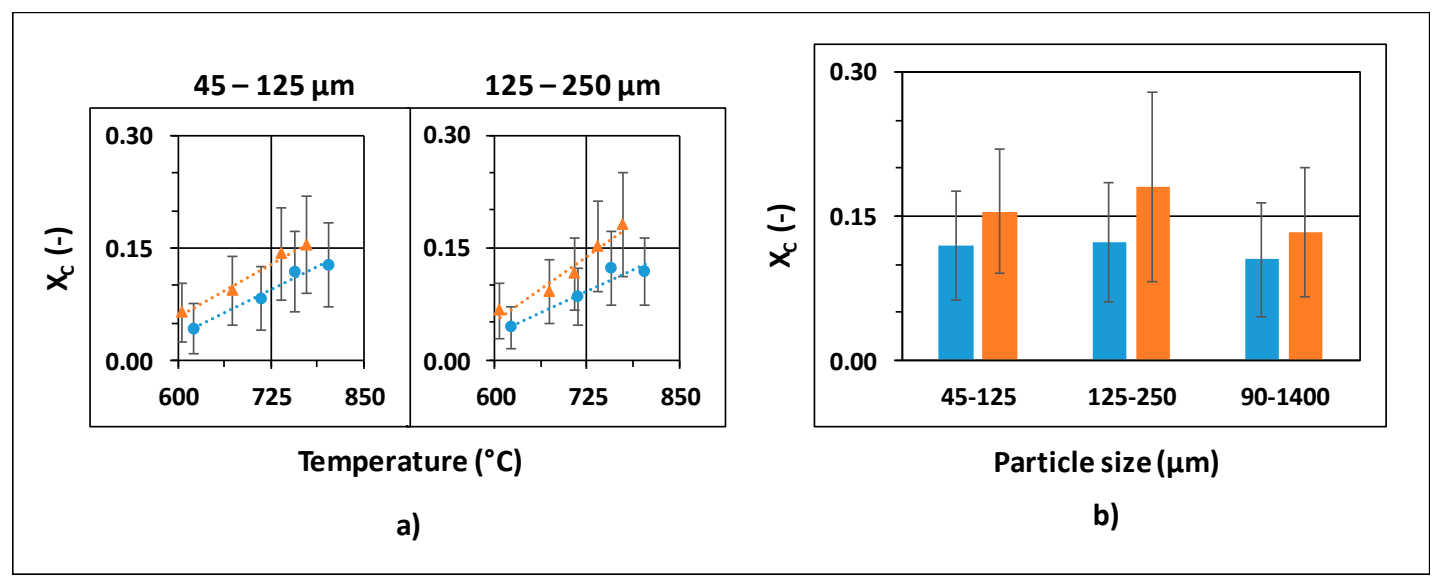

Figure 6. Calculated syngas-based carbon conversion in case of plasma (orange) and thermal (blue) charcoal gasification with systematic errors: (a) variation of gas temperature; (b) variation of particle size at $\mathrm{T}=766^{\circ} \mathrm{C}$.

According to Table 1, the fixed carbon content regarding the total mass is $72.9 \%$ $(=76.4 \% \times(1-4.6 \%))$. Therefore, the carbon content in the volatile matter can be calculated to $7.7 \%$ $(=84.5 \% \times(1-4.6 \%)-72.9 \%)$. With the assumption of equal composition of carbon content in tars and in gases, the $X_{C}$ expected after a complete pyrolysis should be $3.9 \%(=7.7 \% \times 0.5)$ relative to the total mass. In the case of $45-125 \mu \mathrm{m}$ charcoal gasification at $766{ }^{\circ} \mathrm{C}$, the carbon conversion $X_{C}$ is calculated to be ca. $15 \%$, which corresponds to a conversion degree of $12.1 \%(=15 \% \times 84.5 \% \times(1-4.6 \%))$ with respect to the total mass. Considering the possible tar reforming, the released mass content of fixed carbon during gasification is between $4.4 \%(=12.1 \%-7.7 \%)$ and $8.2 \%(=12.1 \%-3.9 \%)$. The authors want to point out that the low carbon conversion degree is due to the limited particle residence time of less than $1 \mathrm{~s}$.

To achieve a higher conversion degree, a higher temperature, a longer residence time and an optimized plasma-feedstock contact [8] can be adopted.

\subsection{Hydrogen Release}

In this work, a parameter $Y_{H}$, defined as syngas-based hydrogen release, is calculated from the hydrogen balance between the hydrogen mass flow in generated syngas $\left(\dot{m}_{H, C H 4}, \dot{m}_{H, H 2}\right)$ minus the 
hydrogen production from the plasma-assisted water dissociation $\left(\dot{m}_{H, p l a s m a}\right)$ and the hydrogen mass flow of feedstock $\left(\dot{m}_{H, f u e l}\right)$ in feedstock. The authors want to point out that the hydrogen release is not equal to the hydrogen conversion from feedstock into syngas, because a certain amount of hydrogen comes from the water steam. Thus, the value of syngas-based hydrogen release can possibly exceed one.

$$
Y_{H}=\frac{\dot{m}_{H, C H 4}+\dot{m}_{H, H 2}-\dot{m}_{H, p l a s m a}}{\dot{m}_{H, f u e l}}
$$

Additionally, the measured hydrogen production from the plasma-assisted water dissociation is potentially lower than the actual production during plasma gasification, because the $\mathrm{H} \cdot$ and $\mathrm{OH}$. radicals can recombine to form water. In the case of charcoal gasification with plasma, the generated $\mathrm{H}$ and $\mathrm{OH}$-radicals can react with feedstock. In summary, the calculated syngas-based hydrogen release offers a possibility to quantitatively determine the influence of NTP on the hydrogen production from charcoal gasification.

Figure 7 presents the hydrogen release in case of plasma-assisted and thermal gasification with systematic errors. In (a), similar temperature-dependent trend lines were observed as those in Figure 6 . In (b), the hydrogen release of different particles has been compared at $\mathrm{T}=766{ }^{\circ} \mathrm{C}$ in the reactor. An average NTP-enhancement of $31 \%$ was calculated.

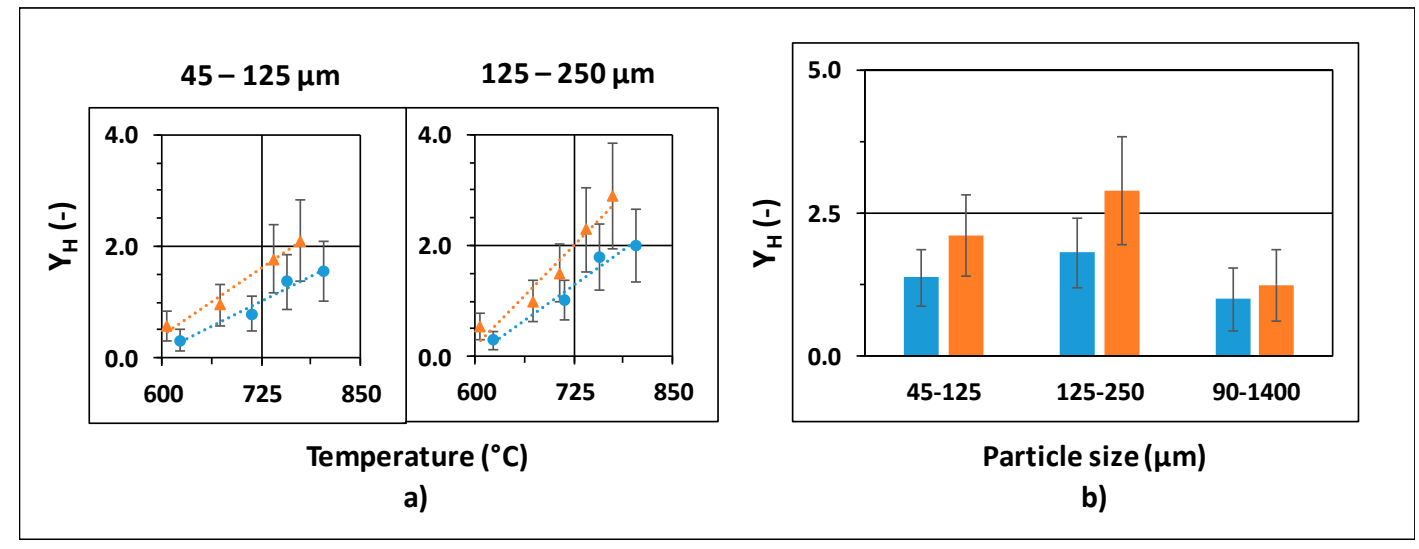

Figure 7. Calculated syngas-based hydrogen release in case of plasma (orange) and thermal (blue) charcoal gasification with systematic errors: (a) variation of gas temperature; (b) variation of particle size at $\mathrm{T}=766^{\circ} \mathrm{C}$.

The relatively high value of $Y_{H}$ in the case of 125-250 $\mu \mathrm{m}$ can be also explained by the fluctuation of screw conveyor; see Chapter 3.3.

\subsection{Reaction Kinetics}

The reaction kinetics are calculated by data-fitting in an Arrhenius diagram for the first reaction order; see [16].

Figure 8 shows the calculated reaction kinetics in case of plasma and thermal charcoal gasification with systematic errors. In (a), the reaction kinetics become faster with the rising gas temperature inside the reactor. In (b), the particle size does not influence the reaction rate coefficient and the NTP promotes the reaction rate coefficient $k$ by $27 \%$ on average.

The calculated reaction kinetics are summarized in Table 4 . The calculated activation energies of plasma-assisted are lower than that of thermal gasification, which confirms the hypothesis of the NTP-induced kinetics promotion. However, the authors want to emphasis the complexity of the overall system including conventional heterogeneous gas-solid and plasma-induced reactions. The results in Table 4 are combined with considerable systematic errors, as shown in Figure 8. 


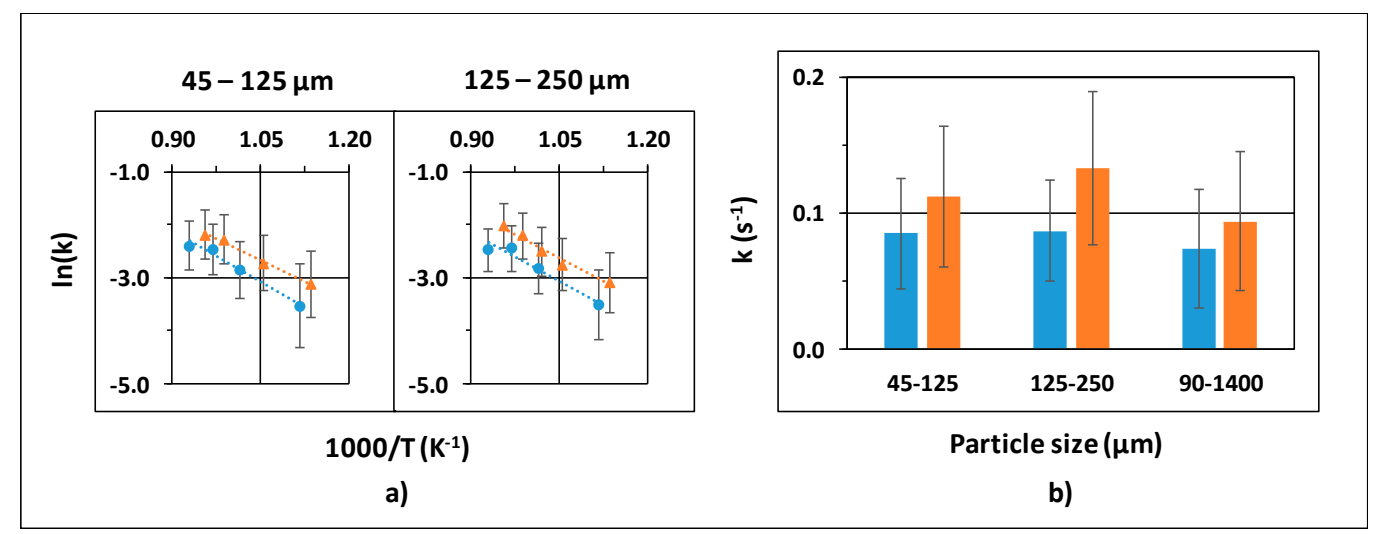

Figure 8. Calculated reaction kinetics in case of plasma (orange) and thermal (blue) charcoal gasification with systematic errors: (a) variation of gas temperature; (b) variation of particle size.

Table 4. Calculated reaction kinetics of own results $\left(k=A \times \exp \left(-E_{A} / R T\right)\right.$, first reaction order).

\begin{tabular}{cccc}
\hline Type of Reaction & Particle Size $(\boldsymbol{\mu m})$ & Ea $(\mathbf{k J} / \mathbf{m o l})$ & $\mathbf{A ~ ( \mathbf { s } ^ { - \mathbf { 1 } } )}$ \\
\hline plasma-assisted & $45-125$ & 43.8 & 17.7 \\
thermal & $45-125$ & 52.6 & 35.2 \\
plasma-assisted & $125-250$ & 49.8 & 38.7 \\
thermal & $125-250$ & 50.0 & 25.4 \\
plasma-assisted & $90-1400$ & 34.0 & 4.6 \\
thermal & $90-1400$ & 38.4 & 6.3 \\
\hline
\end{tabular}

Further test results from the authors regarding plasma-assisted toluene and isopropanol reforming also show the enhancement in reaction kinetics, which will be published in the near future.

\subsection{Cold Gas Efficiency}

The conventional cold gas efficiency is defined as the ratio between the energy flow in syngas $\left(\mathrm{LHV}_{\text {syngas }} \times \dot{\mathrm{m}}_{\text {syngas }}\right)$ and the introduced chemical energy flow of feedstock $\left(\dot{\mathrm{m}}_{\text {fuel }} \times \mathrm{H}_{\mathrm{u}}\right)$. This definition is modified for the plasma-assisted reforming process by taking ca. $1 \mathrm{~kW}$ plasma power $\left(\mathrm{P}_{\text {plasma }}\right)$ and $2.5 \mathrm{~kW}$ heat input through heater $\left(\mathrm{P}_{\text {heater }}\right)$ into consideration. The lower heating value of charcoal is assumed to be ca. $30 \mathrm{MJ} / \mathrm{kg}$.

$$
\mathrm{CGE}_{\text {plasma }}=\frac{\sum\left(\mathrm{LHV}_{\text {syngas }} \cdot \dot{\mathrm{m}}_{\text {syngas }}\right)}{\dot{\mathrm{m}}_{\text {fuel }} \cdot \mathrm{LHV}_{\text {fuel }}+\mathrm{P}_{\text {plasma }}+\mathrm{P}_{\text {heater }}}
$$

The cold gas efficiency for plasma-assisted charcoal steam gasification in case of the particle size between 45 and $125 \mu \mathrm{m}$ is calculated to $5.9 \%$. The authors want to emphasize that this low cold gas efficiency (CGE) is only based on the laboratory scale. Furthermore, in case of a plasma-assisted industrial application, energy input will be supplied by plasma and no electrical heater will be used.

\subsection{Proposed Reacton Mechanism Based on Literature and Own Results}

Based on our own results and the results in the literature, the following plasma-induced reaction mechanism is proposed. The following reactions offer possible pathways of enhanced syngas production in case of plasma-assisted charcoal gasification. However, they represent only a small (possible) part of total plasma-assisted reaction mechanism.

The ionization and dissociation reaction takes place due to an electrical energy input, generating radicals, electrons and ions.

$$
\begin{aligned}
& \mathrm{H}_{2} \mathrm{O}+\text { electrical energy } \rightarrow \text { radicals }(\text { e.g., } \cdot \mathrm{H}, \cdot \mathrm{OH}) \\
& + \text { charged particles }\left(\text { e.g., } \mathrm{e}^{-}, \mathrm{H}^{+}, \mathrm{OH}^{-}\right)+\text {excited particles }+\mathrm{UV} \text { irradiation }
\end{aligned}
$$


Depending on the amount of electrical energy, the ionization and dissociation products can vary [23]. Thus, Reaction (5) gives only a general expression. For the purpose of simplicity, the negative charge of electron is neglected in the following reactions. In an electrical field, the electron can be accelerated to achieve high kinetic energy (e.g., 1-10 eV [24]). The electrons with high kinetic energy are called energetic electrons $\left(\mathrm{e}_{\mathrm{en}}\right)$.

$$
\mathrm{e}+\text { electrical field } \rightarrow \mathrm{e}_{\mathrm{en}}
$$

The enhancement of gas production, carbon conversion and hydrogen release can be explained by electron impact and radical-induced reactions. The symbol $R$ - represents carbon-containing functional groups in the charcoal structure.

$$
\begin{gathered}
\mathrm{e}_{\mathrm{en}}+\mathrm{R}-\mathrm{H} \rightarrow \cdot \mathrm{R}+\cdot \mathrm{H}+\mathrm{e} \\
\mathrm{e}_{\mathrm{en}}+\mathrm{R}-\mathrm{O}-\mathrm{R} \rightarrow \cdot \mathrm{R}+\cdot \mathrm{O}-\mathrm{R}+\mathrm{e}
\end{gathered}
$$

The electron impact reactions (e.g., (7) and (8)) could cause the decomposition of chemical bonds, which indicates an energy transfer from kinetic energy into bond dissociation energy (BDE). According to BDEs listed in Table 5, the chemical bonds could be separated by the kinetic energy of energetic electrons. The probability of these reactions can be determined by the calculation of their reaction enthalpies, which was not done in this work.

Table 5. Selected bond dissociation energy of common bonds [25].

\begin{tabular}{ccc}
\hline Type of Bonds & BDE (kJ/mol) & BDE (eV) \\
\hline H-O & 459 & 4.8 \\
C-H & 411 & 4.3 \\
C-O & 358 & 3.7 \\
C=O & 799 & 8.3 \\
C-C & 346 & 3.6 \\
C=C & 602 & 6.2 \\
C $=$ C & 835 & 8.7 \\
\hline
\end{tabular}

Radicals such as $\cdot \mathrm{H}$ and $\cdot \mathrm{OH}$, generated from water dissociation, have a high oxidation potential, which could also contribute to the destruction of carbon-carbon bonds in charcoal structures (e.g., (9)-(12)). These reactions have been investigated by Mulcahy and Young [26] for the first reaction order. The test results showed the reaction rate of $200-710 \mathrm{~s}^{-1}$ and $100-360 \mathrm{~s}^{-1}$ at $20^{\circ} \mathrm{C}$ for (9), (10) and for (11), (12), respectively.

$$
\begin{gathered}
2 \cdot \mathrm{OH}+\mathrm{C} \rightarrow \mathrm{CO}+\mathrm{H}_{2} \mathrm{O} \\
4 \cdot \mathrm{OH}+\mathrm{C} \rightarrow \mathrm{CO}_{2}+2 \mathrm{H}_{2} \mathrm{O} \\
\cdot \mathrm{OH}+\mathrm{C} \rightarrow \mathrm{CO}+0.5 \mathrm{H}_{2} \\
2 \cdot \mathrm{OH}+\mathrm{C} \rightarrow \mathrm{CO}_{2}+\mathrm{H}_{2}
\end{gathered}
$$

The intermediate (radical) products could react with each other (e.g., (13)-(16)), producing possible final products such as water, hydrogen, and carbon dioxide. This could explain the enhanced gas production shown in Figure 5.

$$
\begin{gathered}
\cdot \mathrm{H}+\cdot \mathrm{OH} \rightarrow \mathrm{H}_{2} \mathrm{O} \\
\cdot \mathrm{H}+\cdot \mathrm{H} \rightarrow \mathrm{H}_{2} \\
\cdot \mathrm{OH}+\cdot \mathrm{OH} \rightarrow \mathrm{H}_{2} \mathrm{O}_{2} \rightarrow \mathrm{H}_{2} \mathrm{O}+0.5 \mathrm{O}_{2} \\
\mathrm{CO}+\mathrm{H}_{2} \mathrm{O} \rightarrow \mathrm{CO}_{2}+\mathrm{H}_{2}
\end{gathered}
$$


The authors want to emphasize that the proposed reaction mechanism based on electron impact and radical oxidation is only a part of the total complex plasma-induced reaction mechanism. Other influencing factors, such as ions, excited particles and UV irradiation, could also contribute to fuel conversion. A review paper of plasma gasification/reforming with focus on reaction mechanism will be published in the near future.

\section{Conclusions}

In this work, charcoal gasification with water steam nonthermal plasma took place in a drop tube reactor. The particle size was varied between 45 and $250 \mu \mathrm{m}$ using two particle size classes.

The nonthermal plasma enhanced the production of $\mathrm{H}_{2}, \mathrm{CH}_{4}, \mathrm{CO}$ and $\mathrm{CO}_{2}$ compared to thermal gasification by $39 \%, 8 \%, 26 \%$ and $29 \%$, respectively. The carbon conversion $X_{C}$ and the hydrogen release $Y_{H}$ were calculated from the individual carbon and hydrogen balance between the corresponding content in the syngas and the content in feedstock. The NTP-enhancements in $X_{C}$ and $Y_{H}$ were $25 \%$ and $31 \%$ respectively. Reaction rate coefficients were determined assuming first order kinetics. Their temperature dependencies were evaluated by data-fitting in an Arrhenius diagram. Nonthermal plasma application was found to accelerate gasification kinetics by $27 \%$. Based on the experimental results, plasma-induced reaction mechanism based on electron impact and radical reactions was proposed.

Author Contributions: Y.P. conceived, designed and performed the experiments; All authors analyzed and evaluated the results; Y.P. wrote the paper.

Acknowledgments: This work was supported by the Campus Future Energy System (Campus FES) under the grant "Biomassevergasung in Nichtthermischen Plasmen". We thank Christian Mauderer for supporting the gasification experiment. We also thank Hannah Bosch for the proofreading. We acknowledge support by Deutsche Forschungsgemeinschaft and Friedrich-Alexander-Universität Erlangen-Nürnberg (FAU) within the funding programme Open Access Publishing.

Conflicts of Interest: The authors declare no conflict of interest.

\section{Nomenclature}

$\begin{array}{ll}\text { A } & \text { Pre-exponential factor } \\ \text { BDE } & \text { Bond dissociation energy } \\ \text { CGE } & \text { Cold gas efficiency } \\ \text { DC } & \text { Direct current } \\ \mathrm{E}_{\mathrm{A}} & \text { Activation energy } \\ \mathrm{k} & \text { Reaction rate coefficient } \\ \dot{m}_{\mathrm{C}, \mathrm{CO}} & \text { Carbon mass flow of carbon monoxide } \\ \dot{m}_{\mathrm{C}, \mathrm{CO} 2} & \text { Carbon mass flow of carbon dioxide } \\ \dot{m}_{\mathrm{C}, \mathrm{CH}} & \text { Carbon mass flow of methane } \\ \dot{m}_{\mathrm{C}, f u e l} & \text { Carbon mass flow of feedstock } \\ \dot{m}_{H, f u e l} & \text { Hydrogen mass flow of feedstock } \\ \dot{m}_{H, H 2} & \text { Hydrogen mass flow of hydrogen } \\ \dot{m}_{H, C H 4} & \text { Hydrogen mass flow of methane } \\ \dot{m}_{H, p l a s m a} & \text { Hydrogen mass flow from the plasma-assisted water dissociation } \\ \mathrm{NTP} & \text { Nonthermal plasma } \\ \mathrm{R} & \text { Gas constant } \\ \mathrm{S} / \mathrm{C} & \text { Steam to carbon } \\ \mathrm{T} & \text { Temperature } \\ X_{\mathrm{C}} & \text { Syngas-based carbon conversion } \\ Y_{H} & \text { Syngas-based hydrogen release }\end{array}$




\section{References}

1. Karl, J. Dezentrale Energiesysteme, Neue Technologien im liberalisierten Energiemarkt; De Gruyter: Berlin, Germany, 2012.

2. Karl, J.; Pröll, T. Steam gasification of biomass in dual fluidized bed gasifiers: A review. Renew. Sustain. Energy Rev. 2018, 98, 64-78. [CrossRef]

3. Li, R.; Zhang, J.; Wang, G.; Ning, X.; Wang, H.; Wang, P. Study on $\mathrm{CO}_{2}$ gasification reactivity of biomass char derived from high-temperature rapid pyrolysis. Appl. Therm. Eng. 2017, 121, 1022-1031. [CrossRef]

4. Bui, H.-H.; Wang, L.; Tran, K.-Q.; Skreiberg, Ø. $\mathrm{CO}_{2}$ gasification of charcoals produced at various pressure. Fuel Process. Technol. 2016, 152, 207-214. [CrossRef]

5. Yuan, S.; Chen, X.; Li, J.; Wang, F. $\mathrm{CO}_{2}$ Gasification Kinetics of Biomass Char Derived from High-Temperature Rapid Pyrolysis. Energy Fuels 2011, 25, 2314-2321. [CrossRef]

6. Wang, G.; Zhang, J.; Shao, J.; Liu, Z.; Wang, H.; Li, X. Experimental and modeling studies on $\mathrm{CO}_{2}$ gasification of biomass chars. Energy 2016, 114, 143-154. [CrossRef]

7. Dahou, T.; Defoort, F.; Thiéry, S.; Grateau, M.; Campargue, M.; Bennici, S.; Jeguirim, M.; Dupont, C. The Influence of Char Preparation and Biomass Type on Char Steam Gasification Kinetics. Energies 2018, 11, 2126. [CrossRef]

8. Yoon, S.J.; Lee, J.-G. Hydrogen-rich syngas production through coal and charcoal gasification using microwave steam and air plasma torch. Int. J. Hydrog. Energy 2012, 37, 17093-17100. [CrossRef]

9. Guizani, C.; Jeguirim, M.; Gadiou, R.; Sanz, F.J.E.; Salvador, S. Biomass char gasification by $\mathrm{H}_{2} \mathrm{O}, \mathrm{CO}_{2}$ and their mixture: Evolution of chemical, textural and structural properties of the chars. Energy 2016, 112, 133-145. [CrossRef]

10. Reschmeier, R.; Karl, J. Experimental study of wood char gasification kinetics in fluidized beds. Biomass Bioenergy 2016, 85, 288-299. [CrossRef]

11. Bouraoui, Z.; Dupont, C.; Jeguirim, M.; Limousy, L.; Gadiou, R. $\mathrm{CO}_{2}$ gasification of woody biomass chars: The influence of $\mathrm{K}$ and $\mathrm{Si}$ on char reactivity. C. R. Chim. 2016, 19, 457-465. [CrossRef]

12. Hengel, T.L.T.D.; Walker, P.L., Jr. Catalysis of lignite char gasification by exchangeable calcium and magnesium. Fuel 1984, 63, 1214-1220. [CrossRef]

13. Tamošiūnas, A.; Chouchène, A.; Valatkevičius, P.; Gimžauskaitè, D.; Aikas, M.; Uscila, R.; Ghorbel, M.; Jeguirim, M. The Potential of Thermal Plasma Gasification of Olive Pomace Charcoal. Energies 2017, 10, 710. [CrossRef]

14. Zhu, J.; Ehn, A.; Gao, J.; Kong, C.; Aldén, M.; Salewski, M.; Leipold, F.; Kusano, Y.; Li, Z. Translational, rotational, vibrational and electron temperatures of a gliding arc discharge. Opt. Express 2017, 25, 20243-20257. [CrossRef] [PubMed]

15. Bahr, L.A.; Fendt, P.; Pang, Y.; Karl, J.; Hammer, T.; Braeuer, A.S.; Will, S. Temperature determination of superheated water vapor by rotational-vibrational Raman spectroscopy. Opt. Lett. 2018, 43, 4477-4480. [CrossRef] [PubMed]

16. Pang, Y.; Bahr, L.; Fendt, P.; Zigan, L.; Will, S.; Hammer, T.; Baldauf, M.; Fleck, R.; Müller, D.; Karl, J. Plasma-Assisted Biomass Gasification with Focus on Carbon Conversion and Reaction Kinetics Compared to Thermal Gasification. Energies 2018, 11, 1302. [CrossRef]

17. Prüfung fester Brennstoffe-Bestimmung des Wassergehaltes und der Analysenfeuchtigkeit (DIN 51718:2002-06); Beuth-Verlag: Berlin, Germany, 2002.

18. Prüfung fester Brennstoffe-Bestimmung des Aschegehaltes (DIN 51719:1997-07); Beuth-Verlag: Berlin, Germany, 1997.

19. Prüfung fester Brennstoffe-Bestimmung des Gehaltes an Flüchtigen Bestandenteilen (DIN 51720:2001-03); Beuth-Verlag: Berlin, Germany, 2001.

20. Prüfung fester Brennstoffe-Immediatanalyse und Berechnung des Fixen Kohlenstoffs (DIN 51734:2008-12); Beuth-Verlag: Berlin, Germany, 2008.

21. Prüfung fester Brennstoffe-Bestimmung des Gesamtgehaltes an Kohlenstoff, Wasserstoff und Stickstoff-Instrumentelle Methoden (DIN 51732:2014-07); Beuth-Verlag: Berlin, Germany, 2014.

22. Backreedy, R.I.; Jones, J.M.; Pourkashanian, M.; Williams, A. Modeling the reaction of oxygen with coal and biomass chars. Proc. Combust. Inst. 2002, 29, 415-421. [CrossRef]

23. Braithwaite, N.S.J. Introduction to gas discharges. Plasma Sources Sci. Technol. 2000, 9, 517. [CrossRef] 
24. Fridman, A. Plasma Chemistry; Cambridge University Press: Philadelphia, PA, USA, 2008.

25. Wired Chemist-Common Bond Energies and Bond Lengths. Available online: http://www.wiredchemist. com/chemistry/data/bond_energies_lengths.html (accessed on 26 September 2018).

26. Mulcahy, M.F.R.; Young, B.C. The reaction of hydroxyl radicals with carbon at 298 K. Carbon 1975, 13, $115-124$. [CrossRef] 